\title{
Hukum Islam dan Lembaga Peradilan Agama pada Awal Kemerdekaan
}

\author{
Mara Ongku Hasibuan \\ Sekolah Tinggi Agama Islam Unggul Indonesia \\ Email: hasibuanongku@gmail.com
}

\begin{abstract}
Tujuan Penelitian ini adalah untuk menganalisa bagaimana perkembangan hukum Islam pada masa awal kemerdekaan dan historisnya. Penelitian ini lakukan untuk mengkaji tentang sumber rujukan hukum Islam dalam Lembaga pengadilan agama di Indonesia. Penelitian bersifat kualitatif dengan dengan menganalisi beberapa buku literatur dan sebagai sumber data utama. Adapun Hasil Penelitian ini dapat disimpulkan bahwa hukum Islam di lembaga peradilan agama pada awal kemerdekaan peradilan Agama pada awal kemerdekaan pengadilan Agama bukan hanya di Jawa dan Madura akan tetapi sudah sampai ke kabupaten dengan sebutan nama Mahkamah Syar'iyah di Aceh propinsinya di Banda Aceh, Pengadilan Agama di Sumatera Utara di Medan Sumatera Barat di Padang. Pengadilan Agama pada masa awal kemerdekaan untuk Jawa dan Madura masih Nikah, talak, dan rujuk ada perkara-perkara yang tidak masuk di dalam kekuasaan Pengadilan Agama seperti Hadhanah, Waris, wakaf, hibah, dan sumber rujukan 13 buku rujukan sebagai pedoman hakim agama dalam mengadili perkara yaitu: al-Bajuri, Fathul Mu'in, Syarkawi Alattahrir, Qulyubi Mahalli, Fatkhul Wahab dengan syarahnya Tuhfah, Tagribul mustag, Qarwanin Syah'ah lil Sayyid bin Yahya, Qawaninus Syariah Us Sayyid Sahdaqah Dahlan, Syamsuh fil Faraid, Bughyatul Murtasyidin, al Figh 'Alaa Mazahibil Arba'ah dan Mughnil Muhtaj.
\end{abstract}

Key Words: Hukum Islam; Peradilan, awal kemerdekaan

\section{PENDAHULUAN}

Sebelum awal kemerdekaan Indonesia dan sebelum Islam datang ke Indonesia telah ada dua macam peradilan yakni peradilan perdata dan peradilan padu, peradilan perdata menangani perkara-perkara yang menjadi urusan raja, sedang pengadilan padu bertugas menangani perkara-perkara yang bukan menjadi urusan raja. (Jalil, 2012) peradilan agama di Indonesia serangkai dengan sejarah masuknya agama Islam ke Nusantara. Penerapan hukum Islam dalam kehidupan kehidupan masyarakat Indonesia sebelum kedatangan kolonial (masa kerajaa-kerajaan Islam ) dalam hal penyelesaian masalah muamalah. Mnakahat, dan uqubat di selesaikan melalalui Peradilan Agama. Walaupun secara yuridis lembaga peradilan Agama belum ada. Tetapi dalam praktinya telah ada penerapan peradilan Agama dalam proses penyelesaian perkara-perkara tersebut (Alaiddin, 2011)

Dapat di tarik benang merah bahwa adanya peradilan Islam di Indonesia bersamaan dengan adanya atau masuknya Islam ke Indonesia setalah masuknya agama Islam selalu ada pegawai khsusus yang mempunyai keahlian dalam hukum Islam, yang kadang-kadang menangani juga urusan mu'amalah, iddah, hadhanah, waris, dan lainnya oleh pegawai yang berlaku untuk seluruh masyarakat Indonesia (Supriyadi, 2008)

Periodisasi peradilan Islam di Indonesia sebelum datangnya pemerinta han kolonial (Belanda) yang di sepakati para ahli terbagi menjadi tiga periode yaitu periode tahkim, Periode Ahlul Halli wa Al Aqdi, dan periode tauliyah. (Alaiddin, 2011) periode tahkim adalah menunjuk seorang hakim jika mereka berselisih pendapat untuk menyelesaikan. Ahl Al Halli wa Al Aqdi adalah 
pengangakatan atas seseorang untuk menjadi hakim, pengangkatan tersebut dilakukan oleh majelis orang-orang terkemuka dalam masyarakat. Sedangkan tauliyah adalah pemeberian kuasa dari sultan atau kepala negara kepada seseorang untuk melaksanakan tugas sebagai hakim.

Undang-Undang Dasa1945 bahwa peradilan Agama merupakan salah satu lembaga lembaga peradilan negara di sampin Peradilan Militer, Peradilan Tata Usaha Negara dan Peradilan Umum, keempat lembaga peradilan tersebut merupakan lembaga kekuasaan kehakiman di Indonesia, yang bertugas menerima mengadili, memeriksa dan menyelesaikan perkara yang diajukan kepadanya (Manan, 2013) Kalau kita lihat di dalam pemerintahan kerjaan Islam sebagai ciri tata pemerinatahan Nusantara pada berikutnya Peradilan Agama memperoleh tempat yang lebih nyata sebagai penasehat Raja di dalam bidang Agama. Dengan di keluarkannya Stbl. 1882 Nomor 152 oleh Pemerintah Kolonial Belanda, yang kemudian di tambah dan dirubah dengan Stbl 1937 No. 116 dan 160 dan Stbl 1937 No 638 dan 639 peradilan Agama di akui sebagai Peradilan Negara meskipun dibiarkan pertumbuhannya tanpa adanya pembinaan sekali (Manan, 2013)

Pemerintah Belanda memang pada awalnya tidak begitu memperhatikan urusan penyelesaian sengketa antar penduduk pribumi di lembaga peradilan Agama. Pada waktu itu VOC hanya mengurusi dirinya sendiri, tetapi setelah pemerintahan penajajahn itu kuat mereka mengadakan pemisahan antara peradilan keduniaan(wereldjlijke rechtpraak), yang di lakukan oleh peradilan Gubernamen, sedangkan peradilan Agama di biarkan tumbuh tanpa pembinaan dan selanjutnya secara berangsur-angsur di kurangi wewenang dan kekuasaannya. (Manan, 2013) Walaupun pada akhirnya Belanda memberi wewenang pada peradilan Islam namun prakteknya pemerintah Belanda tidak tidak memberlakukan sama dengan peradilan lainnya. Seperti gaji Pegawai Peradilan Agama hanya ketua Peradilan Agama saja.

Ketika Jepang berkuasa hampir sama dengan Belanda mereka tidak membayar gari Hakim peradilan Agama khusus pada penghulu apa yang pernah di buat Belanda ada dahulu Jepang tidak mengangkat sebagai pegawai tetap, meskipun pada awalnya Jepang memberikan penghargaan kepada Umat Islam dengan harapan bersedia mendukung perjuangan kemakmuran Asia Timur Raya. Kemudian ada bantahan bahwa penghulu sudah dapat jabatan waktu itu seperti kedudukan sebagai kepala pencatat pernikahan, Imam masjid, Penasehat Bupati, ketua Peradilan agama sudah setara gajinya dengan peradilan yang lainnya (Manan, 2013).

Begitulah kondisi secara singkat peradilan Agama sebelum kemerdekaan bahwa Belanda tidak ingin hukum Islam berlaku seutuhnya sehingga dibedabedakan dengan peradilan yang lain, kalau kita lihat misi Belanda datang ke Indonesia itu secara sosiologis menjalankan misi ganda yaitu ekonomi dan agama. Mereka membiayai orientalis seperti Snouch Hurgronje menghancurkan Islam dari dalam dia pelajari Islam sampai namun misinya adalah untuk melihat kelemahan Islam. Selanjutnya bagaimankah peradilan Islam pada masa awal kemerdekaan.

\section{MEDOTE}

Metodologi penulisan ini yang di analisis dalam penyusunan Penelitian ini menggunakan studi pustaka/ library Research yaitu penelitian berdasarkan bahan-bahan kepustakaan yang berkaitan dengan judul Penelitian ini.

\section{HASIL DAN PEMBAHASAN Keadaan Peradilan masa Belanda}

1. Periode sebelum Tahun 1882 
Sebelum kemerdekaan Indonesia di kuasai oleh Belanda seperti dalam peradilan sekalipun awalnya tidak memperhatikan namun pada ujungnya Belanda ingin menguasai segala bidang karena sudah terlihat jelas di tandai dengan kedatangan organisasi dagang Belanda VOC (vereenigde OostIndische Compagnie), tahun 1596 di Banten, di mana misi dari VOC sebagai perpanjangan tangan pemerintah Belanda mempunyai dua fungsi yaitu ; pertama, sebagai pedagan, kedua, sebagai badan pemerintah. Sebagai upaya pemantapan pelaksanaan kedua fungsi tersebut, VOC menggunakan hukum dan peraturan perundang-undangan Belanda. Di daerahdaerah yang kemudian satu persatu dapat di kuasai kolonial akhirnya akhirnya membentuk Badan Peradilan, upaya ini tidak secara mulus berjalan, dan dalam penerapannya mengalami hambatan (Adbul, 2000).

Tahun 1602 Belanda telah mendirikan VOC (vereenigde OostIndische Compagnie), dalam akad pendiriang yang ditetapkan Staten General (Badan Pemerintahan Tertinggi), VOC diberi hak dan kekuasaan untuk memperkuat dan menyelamatkan perniagaan. Selain itu VOC diberi hak untuk mempunyai atau memilki tanah dan untuk tempat tinggal, mereka mengadaka perjanjian dengan raja-raja serta mengangkat hakim-hakim untuk menjaga keamanan (R, 2015).

Pada awalnya hukum yang diterpkan di daerah kekuasaan VOC adalah hukum Belanda, baik hukum tata negara, hukum perdata, maupun hukum pidana. Tidak ada perbedaan antara orang Indonesia dan Belanda semuanya termasuk ke dalam Badan-Badan Peradilan Belanda, yaitu Raad Van Justitie dan Schepenbank. Dengan demikian maka pengadilan asli yang di lakukan oleh kepala-kepala rakyat menjadi tida ada. Raad Van Justitie merupakan badan pengadilan yang mengadili pegawai-pegawai VOC dan serdadu- serdadunya. Raad Van Justitie mempunyai dua fungsi pertama, sebagai badan pengadilan tingkat pertama dan terakhir untuk pegawai dan serdadu VOC. Kedua, Sebagai pengadilan apple bagi penduduk kota yang minta bandingan keputusan-keputusan Schapenbank. Schepenbank merupakan badan pengadilan bagi semua penduduk yang merdeka (bukan budak) dari semua bangsa kecuali pegawai dan serdadu VOC. Schepenbank yang berwenang mengadili perkara sipil dan criminal (R, 2015).

VOC pada realitanya tidak bisa memberlakukan hukum itu secara menyeluruh hanya di daerah-daerah tertentu saja, akhirnya VOC membiarkan hukum-hukum setempat berjalan sebagaimana sebelumnya bahkan dalam Statuen Van Batavia (statua batavia) 1642 yang merupakan kodifikasi peraturan perdata dan pidana. Kemudian mereka mnyusun buku hukum yang bernama compendium freijer yang berisi hukum perkawinan dan waris Islam dan disahkan tahun 1760. compendium freijer diberlakukan di pengadilan-pengadilan untuk menyelesaikan sengketa di kalangan umat Islam. Selain compendium freijer terbit pula kitan Muharrar untuk pengadilan negeri Semarang yang memuat hukum-hukum Jawa yang mencerminkan hukum Islam. Terbit pula kitab Papakam Cirebon yang berisi kumpulan-kumpulan Jawa yang tua seperti kitab Hukum Raja Niscaya, Undang-Undang Mataram, Jaya Lengkara, Kontra Menawa, dan Adidullah. Papakem Cirebon juga berisi mengenai pengadilan 7 jaksa yang diberi nama Pengadilan Karta dan Penghadilan Penghulu (R, 2015).

Campur tangan pemerintah penjajah Belanda pertama kali di lakukan dalam soal peradilan Agama di mulai tahun 1820 pada saat itu pemerintah penjajah Belanda menginstruksikan kepada seluruh Bupati di Jawa dan Madura agar 
perselisihan mengenai waris antar orangorang Islam diserahkan kepada para ulama yang ahli dalam bidang hukum Islam untuk menyelesaikannya instruksi ini dikenal dengan Regenten Istructie. (Manan, 2013) Pemerintah Belanda sendiri waktu itu hampir pertengahan abad ke-18, berusaha menyusun bukubuku hukum Islam sebagai pegangan hakim-hakim pengadilan (landraad) dan pejabat pemerintahan dalam statua Jakarta 1642 bahkan hukum kekeluargaan di akui dan diterapkan dengan peraturan Resolute der Indiesche Regeering pada 25 Mei 1760. Yang merupakan aturan hukum perkawinan dan hukum kewarisan Islam, atas perkembangan ini maka di kenal dengan beberap compendium yang di susun oleh pejabat-pejabat Belanda dari pakar hukum, misalnya conpendium van Clookwijk, (gubernur Sulawesi Utara 1752-1755) (Manan, 2013).

Kemudian dalam Stbl 1835 Nomor 58 di nyatakan lebih tegas lagi tentang Peradilan Agama di Jawa dan Madura yaitu menyelesaikan segala sesuatu perselisihan tentang perkawinan dan pembagian harta yang menurut pandangan masyarakat Islam harus di putus menurut keputusan hukum Islam. Semenjak tahun 1800, para ahli hukum dan ahli kebudayaan Belanda mengakui bahwa di kalangan masyarakat masyarakat Indonesia Islam merupakan agama yang sangat di junjung tinggi oleh pemeluknya, penyelesaian masalah kemasyarakatan senantiasa merujuk kepada agama Islam. Baik itu soal ibadah, politik , ekonomi dan yang lainnya. Dan hal tersebut Belanda berkeyakinan bahwa di tengah-tengah komunitas itu berlaku hukum Islam, termasuk dalam mengurusi peradilan agama. Hukum Islam dalam perspektif Belanda dan umumnya Barat di pahami adalah hanya persoalan ibadah dan halhal yang terkait erat dengan ritualitas semata. Oleh sebab itu apa yang mereka amati hanyalah sebagian kecil dari ajaran Islam.

Usaha Raja Belanda untuk membentuk Peradilan Agama di daerah jajahannya baru di laksanakan pada tahun 1882, pada waktu itu pemerintah Belanda mengeluarkan keputusan nomor 24 tanggal 12 Januari 1882 di muat dalam Stbl.

2. Periode 1882 sampai 1937

Tanggal 1 Agustus 1882, keputusan Raja Belanda (Konninkklijk Beslui), No. 24 Raja Williem III dinyatakan mulai berlaku. Keputusan yang dimuat dalam staatsblad 1882 Nomor 152 tentang pembentukan peradilan Agama di Jawa dan Madura. (Manan, 2013) Keputusan Raja Belanda ini di nyatakan berlaku mulai 1 Agustus 1882. Yang di muat dalam Staatsblad 1882 No. 153 sehingga dengan demikian dapatlah dikatakan tanggal kelahiran Badan Peradilan Agama di Indonesia adalah 1 Agustus 1882. (Adbul, 2000) Staatsblad 1882 No 152 berisi 7 pasal yang maksudnya adalah sebagai berikut :

\section{Pasal 1}

Disamping setiap landraad (Pengadilan Negeri) di Jawa dan Madura di adakan satu Pengadilan Agama, yang wilayah hukumnya sama dengan wilayah hukum landraad.

\section{Pasal 2}

Pengadilan Agama terdiri atas ; Penghulu yang diperbantukan kepada Landraad sebagai ketua. Sekurangkurangnya dan sebanyak-banyaknya delapan orang Ulama Islam sebagai anggota. Mereka di angkat dan diberhentikan oleh Gubernur /Residen.

\section{Pasal 3}

Pengadilan Agama tidak boleh menjatuhkan putusan kecuali di hadiri oleh sekurang-kurangnya tiga orang anggota, termasuk Ketua, kalau suara sama banyak maka suara ketua yang menentukan,

\section{Pasal 4}

Keputusan Pengadilan Agama di tuliskan dengan disertai alasan- 
alasannya yang singkat. Juga harus di beri tanggal dan di tandatangani oleh para anggota yang turut memberi keputusan. Dalam berperkara itu disebutkan pula jumlah ongkos yang di bebankan kepada pihak-pihak yang berperkara.

\section{Pasal 5}

Kepada pihak-pihak yang berperkara harus diberikan salinan surat keputusan yang di tandatangai oleh Ketua.

\section{Pasal 6}

Keputusan Pengadilan Agama harus di muat dalam suatu daftar yang harus di serahkan kepada Residen setiap 3 bulan sekali untuk memperoleh penyaksian (visum) dan pengukuran.

\section{Pasal 7}

Keputusan Pengadilan Agama
yang melampaui $\begin{array}{r}\text { batas } \\ \text { wewenang/kekuasaannya atau tidak }\end{array}$
memenuhi ketentuan ayat (2), (3), dan
(4) di atas tidak dapat dinyatakan
berlaku.

Kalau di perhatikan isi dari pasal tersebut di atas tidak merumusakan kewenangan peradilan Agama dan tidak pula membuat garis pemisah yang tegas antara peradilan Agama dan pengadilan Negeri. Kebijakan politik untuk tidak mencampuri urusan agama sebenarnya hanya bersifat sementara, dengan pertimbangan Belanda belum menguasai hukum Islam sehingga di khawatrikan akan timbul perlawanan. Sebagai antisipasi, Belanda mengangkat Snouck Hurgronje pada tahun 1889 sebagai penasehat yang menyangkut politik menghadapi orang Islam. Keinginan pemerintah Belanda untuk memberlakukan hukum Belanda bagi semua golongan yang terkenal dengan unifikasi hukum mendapat tantangan dari Snouck Hurgronje dan kawan-kawan. (R, 2015).

Van den Berg (1845-1927), Selain Van Den Berg, Prof Dr. Snouck Hurgronye (wafat 1936), Snouck ini seorang Orientalist yang besar dan ternama ia pandai sekali dalam agama Islam tahu sekali adat istiadat kaum muslimin, terutama kaum muslimin Indonesia beliau pernah menyamar masuk Mekkah sebagai dokter mata beragama Islam dan bergelar Haji Abdul Gaffar, ia di Mekkah pada tahun 18841885, di Mekkah ia mempelajari bahasa Arab semahir-mahirnya pandai mengartikan Quran Hadis pandai mengaji tafsir ia belajar kepada ulama-ulama ternama di Mekkah ketika itu ia kembali ke Indonesia dan pernah tinggal di Semarang kawin di sana, juga pernah tinggal di Aceh, dan menyelidiki adat istiadat kaum muslimin Aceh yang keras yang tidak mau tunduk kepada Belanda.

Kemudian ia memberi adpis kepada pemerintahan kolonial Belanda, bagaiaman caranya menundukkan orang Aceh itu (Abbas, 2004) seorang sarjana Belanda berkesimpulan bahwa pada awal masa penjajahan Belanda bagi orangorang Indonesia yang beragama Islam berlaku teori, receptio in complexu yang berarti orang-orang muslim Indonesia menerima dan memberlakukan syariat Islam secara keseluruhan (Adbul, 2000)

Tetapi Snouck Hurgronje menentang pendapat L. W.C dan Van den Berg, Snouck mulai dengan jalam pikiran baru yang berlawanan yang kemudian pendapatnya di kenal dengan sebutan teori reseptie, tidak ada satu rumusan jelasa atau aturan tertentu antara ahli hukum Belanda dengan teori reseptie ini. Di kemukakan bahwa sebenarnya yang berlaku di Indonesia adalah hukum adat asli. Sedikit pengaruh hukum Islam masuk ke dalam hukum adat. Pengaruh hukum Islam akan mempunyai kekuatan bila sudah diterima oleh hukum adat sehingga lahirlah ia sebagai hukum adat dan bukan sebagai hukum Islam (Jalil, 2012).

Usaha yang dilakukan oleh Snouck Hurgoronje mempengaruhi masyarkat dengan teori receptie, tujuan utamanya 
adalah agar terjadi benturan antara hukum adat, hukum Islam dan hukum Belanda. Usaha ini berhasil dan sampai sekarang posisi hukum Islam masih sangat terjepit di antara hukum adat dan hukum Belanda (R, 2015).

Pada tahun 1930 pemerinah mengambil kebijaksanaan menempatkan pengadilan Agama di bawah pengawasan landraad, sejak itu Pengadilan Agama mulai hilang kebebasannya. Putusan Pengadilan Agama memerlukan pengukuhan, dari Landraad dan dinyatakan tidak berwenang melakukan penyitaan atas barang atau uang (Abdurrahman, 1994)

Pada tahun 1931 berdasar atas usul dan saran Priesterraden Commiise, maka ordonantie tanggal 31 Januari 1931 yang tersebut dalam staablad 1931 No. 53 ditetapkan peraturan tentang 3 pokok ketentuan, pada bagian I tentang Peradilan Agama berisikan:

a. Bentuk pengadilan Agama sebagai Priesterrad atau disebut pula Raad Agama, dirubah menjadi penghoelole Gerecht yang terdiri atas seorang penghulu sebagai hakim, di dampingi dua orang penasehat dan seorang griffer (panitera).

b. Kekuasaan Pengadilan Agama dibatasi hanya memeriksa perakara-perkara yang bersangkutan dengan nikah, talak dan rujuk, Hadhanah, wakaf dan lain lain seabagainya dicabut dan diserahkan kepada landraad.

c. Di adakan beberapa tambahan tentang acara pada Pengadilan Agama

d. Di adakan Mahkamah Islam Tinggi sebagai Badan Peradilan banding atas keputusan Pengadilan Agama.

Kekuasaan Mahkamah Islam Tinggi pada pokoknya adalah sebagai hakim tertinggi dalam dua bidang yaitu :

1. Memutuskan perselisihan tentang kekuasaan antara Pengadilan Agama yang dimintakan banding oleh orang yang bersangkutan.

2. Mahkamah Islam Tinggi berkewajiban untuk memberikan saran-saran pertimbangan masalah Agama Islam apabila di minta oleh Gubernur Jenderal atau pembesar lain atas perintahnya.

Pada tahun yang sama dikeluarkan ketetapan pemerintah yang berkaitan dengan peradilan Agama di luar Jawa dan Madura. Melalui Staatsblad 1937 No. 638 dan No. 639 didirikan kerapatan Qodli dan kerapatan Qodli besar di Kalimantan Selantan dengan wewenang persis seperti Pengadilan Agama di Jawa dan Madura. Akibat dari politik kolonial Belanda yang berusaha menempatkan hukum Islam di posisi yang lemah dan menggantikannya dengan hukum adat pada pertengahan abad XIX $M$ itu membuat hukum Islam sulit berkembang sampai sekarang (R, 2015)

Menurut Supomo, pada masa penjajahan Belanda terdapat lima tatanan peradilan yaitu :

1. Peradilan Geburnemen, tersebar di seluruh daerah Hindia Belanda

2. Peradilan pribumi tersebut di luar Jawa dan Madura, yaitu di Keresidenan Aceh, Tapanuli, Sumatera Barat, Jambi, Palembang, Bengkulu, Riau, Kalimantan Barat, kalimantan Selatan, dan Timur.

3. Peradilan Swapraja, tersebar hampir di seluruh daerah swapraja, kecuali di pakualaman dan Pontianak.

4. Peradilan Agama tersebar di daerahdaerah tempat berkedudukan Peradilan Gubernamen, di daerah-daerah dan menjadi bagian dari Peradilan Pribumi.

5. Peradilan Desa tersebar di daerahdaerah tempat berkedudukan Peradilan Gubernamen. Di samping itu ada juga Peradilan Desa yang merupakan bagian dari Peradilan Pribumi atau peradilan Swapraja (Alaiddin, 2011)

Pernah pemerintah Belanda mengurangi kekuasaan pengadilan Agama dalam masalah waris, wakaf, hadhanah, sebagaimana berdasarkan Stbl. 1937 Nomor 610 bertepatan dengan tanggal 1 Januari 1938 dibentuklah 
Mahkamah Islam tinggi untuk wilayah Jawa dan Madura, dalam isinya ada tindakan pemerintah Belanda mengurangi kekuasaan peradilan Agama reaksi keras datang dari masyarakat sehingga para penghulu mengadakan kongres di Surakarta pada tanggal 1 Mei 1937, dalam keputusannya permohonan kepada Gubernur Jenderal pemerintah Belanda di Jawa dan Madura mencabut Stbl 1937 Nomor 116 dan diadakan peraturan baru tentang pengadilan Agama yang kewenangannya sesuai dengan kebutuhan masyarakat (Manan, 2013).

Sampai tahun 1882, politik hukum pemerintah Hindia Belanda masih berpihak pada umat Islam. Selain di akui peradilan Serambi kemudian di beri nama Peradilan Agama. Sabagai salah satu badan peradilan yang sah sejajar dengan badan peradilan lainnya, yaitu landraad. Pengadilan negeri, pemerintah Hindia Belanda juga tidak mencampuri urusan pelaksanaan hukum Islam di Bumi Nusantara. Sebagaimana dalam UndangUndang Hindia Belanda ayat 119 RR: “ setiap warga negara bebas menganut pendapat agamanya, tidak kehilangan perlindungan masyarakat dan anggotanya atas pelanggaran peraturan umum hukum agama" (Arifin, 2013).

Politik hukum belanda memang musuh dalam selimut, sebagaimana penerapan ide-ide Snouck Hurgronje sangat ampuh menciptakan dan menyuburkan politik devide et ampera di Indonesia. Dari sudut pandang ini tampak dengan jelas politik hukum untuk menghambat meluas dan di amalkannya hukum Islam di tengah-tengah masyarakat muslim. Mereka menciptakan konsep hukum tandingan demi terlaksananya politik pecah belah tersebut (Adbul, 2000)

\section{Masa Jepang}

Indonesia cukup berduka setelah Belanda, tidak berhenti sampai di situ saja kemudian Jepang memasuki lagi. Jepang datang ke Indonesia pada awal tahun 1942 pada tanggal 9 maret 1942, setelah bertempur selama tujuh hari, Belanda akhirnya menyerah dan kekuasaannya di Indonesia di ambil alih oleh Jepang. Kemeangan tentara Jepang itu tidak lepas dari bantuan rakyat Indonesia yang sudah lama ingin mengusir penjajah Belanda di tambah lagi dengan propoganda Jepang sebagai saudara jauh, rakyat Indonesia dan juga cahaya dari Asia (Angga Priyatna, Aditya fauzan Hakim, 2013).

Rakyat Indonesia pun menyambut kedatangan Jepang dengan suka cita, lalu di bentuklah Putera(Pusat Tenaga Rakyat), untuk membantu Jepang dalam pertempuran Asia Timur melawan tentara sekutu. Pada akhirnya Rakyat Indonesia bergerak melawan Jepang ribuan rakyat Indonesia tewas karena sistem kerja paksa, banyak juga trauma akibat penyiksaan yang tidak berperi kemanusiaan dari tentara Jepang (Angga Priyatna, Aditya fauzan Hakim, 2013).

Dalam bidang peradilan, Jepang membuat kebijakan terhadap undangundang dan pengadilan semua peraturan perundang-undangan yang berasal dari pemerintah Belanda dinyatakan tetap berlaku sepanjang tidak bertentangan. Peradilan Agama tetap di pertahankan dan tidak mengalami perubahan, kecuali namanya di ganti dengan soo-rioo Hooin untuk pengadilan Agama dan kaikoo kootoo Hooin untuk mahkamah Islam Tinggi berdasarkan peraturan peralihan pasal 3 bala tentara Jepang (Osanu Seizu ), tanggal 7 Maret 1942 No. 1 (Jalil, 2012).

Pada tanggal 29 April 1942, pemerintah bala tentara Dai Nippon mengeluarkan UU No. 14 tahun 1942, tentang Pengadilan Bala Tentara Dai Nippon dalam pasal 1 disebutkan bahwa di tanah Jawa dan Madura telah di adakan "Gunsen Hooin", (Pengadilan Pemerintah Bala Tentara), dalam UU ini tidak di jelaskan secara lengkap, pasal 3 UU ini menyebutkan bahwan untuk sementara 
waktu "Gunsen Hooin" (Pengadilan Pemerintah Bala Tentara), terdiri atas, pertama, Tiho Hooin(Pengadilan Negeri ), kedua, Kizai Hooin (Hakim Polisi), ketiga, Ken Hooin(Pengadilan Kabupaten) keempat, Kiaikkoya Kootoo Hooin(Mahkamah Islam Tinggi), kelima, Sooryo Hooin (Rapat Agama), pernah terjadi ancaman tatkala akhir januari 1945 Pemerintah Bala Tentara Jepang mengajukan pertanyaan kepada Dewan Pertimbangan Agung dengan maksud Jepang akan memberikan kemerdekaan kepada bangsa Indonesia (Jalil, 2012) begitulah sekilas keadaan peradilan Agama di Indonesia sebelum kemerdekaan.

Pasa masa kependudukan Jepang kedudukan Peradilan Agama sempat terancam ketika akhir Januari 1945, pemerintah Jepang mengajukan pertanyaan kepada Dewan Pertimbangan Agung (Sanyo-Aanyo Kaigi Jimushits ), tentang cara mengurus kas masjid dan susunan Penghulu dalam hubungan Negara Indonesia Merdeka. Jawaban dari Dewan diberikan tanggal 14 April 1945 sebagai berikut :

"Dalam negara baru yang memisahkan urusan negara dengan urusan agama tidak perlu mengadakan Pengadilan Agama sebagai pengadilan istimewa, untuk mengadakan seseorang yang bersangkut paut dengan agamanya cukup segala perkara diserahkan kepada pengadilan biasa yang dapat minta pertimbangan seorang ahli agama"

Di pihak lain dari golongan Sekuler Sartono menghendaki agar peradilan agama di hapus saja. Dalam surat yang dikirim kepada pemerintah Jepang. Ia menulis: "cukuplah segala perkara di serahkan ke pengadilan biasa yang dapat meminta pertimbangan seorang ahli agama". Sementara Soepomo yang menjadi penasehat pemerintah Jepang juga menentang pemulihan kembali wewenang Pengadilan Agama. Akan tetapi pemerintah Jepang memilih tidak ikut campur dalam masalah keagamaan demi keamanan dan ketertiban, Jepang pada akhirnya kalah perang dan Indonesia memproklamirkan kemerdekaannya tidak perubahan yang berarti bagi Peradilan Agama (R, 2015)

\section{Awal Kemerdekaan}

Ketika terjadi kekosongan karena Jepang telah menyerah dan tentara Sekutu belum mendarat di Indonesia rakyat Indonesia yang diwakili oleh tokoh pejuang bangsa berhasil menyusun naskah Proklamasi tepatnya pada 17 Agustus 1945 kemerdekaan Indonesia diproklamasikan oleh Soekarno dan Hatta atas nama bangsa Indonesia ke segenap pelosok Tanah Air dan dunia (Endang, 1986).

Proklamasi disusun di rumah Laksmana Muda Tadashi Maeda, Jalan Imam Bonjol, Jakarta dan memproklamasikan Indonenesia pada 17 Agustus 1945, di jalan Pengangsaan Timur nomor 56 Jakarta. Naskah Proklamasi tersebut disusun oleh Ir. Soekarno, Drs. Mohammad Hatta, dan Mr. Achmad Soebardjo. Proklamasi merupakan momentum pembebasan dan berakhirnya penjajahan mengantarkan rakyat Indones ia untuk memulai kehdiupan bernegara, dan melanjutkan cita-cita perjuangan sebagai Negara Indonesia yang merdeka (MPR, 2012).

Setelah Indonesia merdeka 17 Agustus 1945, atas usul menteri Agama yang di setujui menteri Kehakiman, pemerintah menetapkan bahwa peradilan di serahkan dari kekuasaan kementerian Kehakiman kepada kemeneterian Agama dengan ketetapan pemerintah nomor 5/SD tanggal 25 Maret 1946. Sebelum merdeka pegawai pengadilan agama dan hakim tidak mendapat gaji tetap dan honorarium dari pemerintah, maka setelah merdeka anggaran belanja pengadilan agama disediakan oleh pemerintah, meskit ketua pengadilan 
agama mendapat gaji pada masa kolonial Belanda, tetapi ketika itu gaji itu diberikan bukan atas nama sebagai pegawai pengadilan agama, tetapi menerima gaji sebagai Islamitisch Adviseur pada Landraad (Adbul, 2000).

Pada masa awal kemerdekaan terjadi perubahan dalam pemerintahan tetapi tidak tampak perubahan yang menonjol dalam tata peradilan, khususnya Peradilan Agama di Indonesia (PADI ), hal tersebut diebabkan karena bangsa Indonesia di hadapkan kepada revolusi fisik dalam menghadapi Belanda yang kembali akan menjajah. Selama revolusi fisik terdapat beberapa hal yang perlu di cermati ;

a. Keluarnya UU Nomor 22 Tahun 1946 tentang pencatatan Nikah, Talak, Rujuk, menggantikan ordonasi NTR dulu. Karena berdasarkan pertimbangan peraturan NTR yang di atur dalam Huwelijksordonantie S. 1929 No. 348 jo s. 1931 No. 467, vorszenlandsche huwelijksordonantie Buitengewesten 8. 1932 No 482 tidak sesuai lagi dengan keadaan saat itu. Pada akhirnya tanggal 21 November 1946 disahkan UU Nomor 22 Tahun 1946 tentang Pencatatan Nikah, Talak, Rujuk, walaupun hanya berlaku di Jawa dan Madura (Alaiddin, 2011). Pada tanggl 23 Tahun 1946 mengambil langkah-langkah Departemen Agama sehubungan dengan adanya penetapan pemerintah tersebut yaitu mengeluarkan maklumat Menteri Agama II yang isinya sebagai berikut ; (1) Shuumuka yang pada zaman Jepang berada di karsidenan dan saat ini menjadi Jabatan Agama Daerah, sekarang menjadi urusan Departemen Agama Pusat, (2) hal untuk mengangkat Penghulu landraad, penghulu beserta dua anggotanya yang saat itu berada di tangan Residen, diserahkan kepada Departemen Agama Pusat. (3) hak untuk mengangkat penghulu masjid dan pegawainya yang sebelumnya menjadi wewenang Bupati, saat setelah penyerahan itu diserahkan kepada Departemen Agama Pusat. (4) ditetapkan Undang-Undang Nomor 22 Tahun 1946 tentang nikah, talak rujuk, pada tanggal 22 November 1946 untuk mengganti ordonantie Pencatat NTR sebelumnya (Manan, 2013).

b. Keluarnya penetapan Menteri Agama Nomor 6 Tahun 1947 tentang penetapan formasi Pengadilan Agama terpisah dari penghulu kabupaten, dengan kata lain pemisahan tugas antara penghulu kabupaten sebagai kepala pegawai pencatat Nikah dan urusan kepenghuluan lainnya serta urusan kemasjidan dengan hakim sebagai ketua Pengadilan Agama hal ini diadakan setelah semua penghulu dan pegawainya sampai ke tingkat kecamatan di angkat menjadi pegawai negeri.

c. Keluarnya UU Nomor 19 Tahun 1948 tentang susunan dan kekuasaan BadanBadan Kehakiman dan kejaksaan yang di tetapkan Wakil Presiden Mohammad Hatta dan Menteri Kehakiman Soesanto Tirtoprojo di Yogyakarta tanggal 08 juni 1948. Dinyatakan tidak pernah berlaku isinya antara lain di hapuskannya susunan Pengadilan Agama yang telah ada sebelumnya sebab dalam pasal 6 ayat 1 UU No. 19/1948 berbunyi : dalam negara republik Indonesia ada tiga lingkungan peradilan yaitu : (1) Peradilan Umum, (2) Peradilan Tata Usaha Pemerintahan, (3) Peradilan Ketentaraan. Dengan demikian berarti Pengadilan Agama dihapuskan kemudian di gabungkan dalam peradilan umum. Terhadap policy UU tersebut timbul reaksi dari berbagai pihak dari ulama Sumatera seperti Aceh, Sumatra Barat, Sumatera Selatan menolak kehadiran UU Nomor 19 Tahun 1948 bahkan para ulama mengusulkan agar Mahkamah Syar'iyah yang sudah ada tetap berjalan dan di atur oleh Menteri Agama dan Menteri Kehakiman.

Keputusan Recomba Jawa Barat No, Rec, Wj 229/72 tanggal 2 April 1948 dan peraturan yang tercantum dalam javaassche Courant 1946 No, 32 dan 39 
tahun 1948. No. 25 dan Tahun 1949 No. 29 dan 65 menentukan bahwa di daerahdaerah yang di kuasai tentara Sekutu dan Belanda, instansi yang bernama priesterraad di ubah menjadi penghulu gerecht.

Di luar Jawa, Madura, Kalimantan Selatan, di kenal berbagai macam pengadilan Agama, tetapi lembaga tersebut merupakan bagian dari Peradilan Adat dan Peradila Swapraja. Lembaga peradilan Islam tersebut terlihat dalam bentuk-bentuk sebagai berikut ; (1) di daerah negara bekas Sumatra Timur di kenal adanya Majelis Agama Islam yang menyelelsaikan perselisihan antara umat Islam. Majelis ini dibentuk berdasarkan ketetapan Wali Negara ST. Nomor 78 tahun1950. kemudian surat keputusan Wali Negara ini dikuatkan dengan keputusan Menteri Agama Nomor 2 Tahun 1953 yang telah mengakui Majelis Agama itu sebagai Pengadilan Agama dan diberi wewenang selain NTR juga masalah kewarisan, wakaf dan hibah menurut hukum Islam. (2) Selain di Sumatera Timur, di bagian pulau Sumatera lainnya terdapat Mahkamah Syari'ah seperti di daerah Aceh, Tapanuli Selatan, Sumatra Tengan Riau, Jambi, Lampung, Palembang dan sekitarnya.

Pembentukannya dilaksanakan pada tanggal 1 Agustus 1946, sesuai dengan pengakuan Wakil Pemerintah Pusat Darurat di Pematang Siantar melalui surat kawat tertanggal 13 Januari 1957. (3) Daerah Bengkulu, Pontianak dan sekitarnya dalam mengadili perselisihan antar ummat Islam telah ada Mahkamah Balai Agama. Demikian juga di daerah Sumbawa, Sulawesi dan sebagian Kalimantan Timur sudah ada Mahkamah penyelesaian sengketa Islam. Peradilan tersebut tetap diperkenankan menjalankan tugasnya dengan kewenangan sebagaimana tersebut dalam pasal 12 Stbl. 1932 Nomor 82 (Manan, 2013)

Pada 1954 terdapat usulan untuk membentuk suatu badan dalam rangka melayani masalah perkawinan dan perceraian ide tersebut semula di cetuskan oleh S. M. Nasruddin Latif kepala KUA Jakarta akhirnya terbentuklan BP4 (Badan Penasehat Perkawinan dan Penyelesaian Perceraian), pada Oktober 1954 di Bandunng berbentuklah BP 4 yang pertama, pada prinsipnya dalam urusan perceraian, BP4 merupakan sebuah badan untuk memberikan nasihat kepada suam istri agar rukun kembali (Alaiddin, 2011).

Pada masa berikutnya berdasarkan ketentuan Pasal 98 UUD sementara dan Pasal 1 ayat (4) UU Darurat Nomor 1 Tahun 1951 pemerintah mengeluarkan PP Nomor 45 Tahun 1957 tanggal 05 Oktober 1957, tentang pembentukan Pengadilan Agama /Mahkamah Syari'ah di luar Jawa dan Madura terutama di daerah Aceh untuk memenuhi kehendak masyarakat setempat sekaligus untuk meredakan suasana keamanan dan ketertiban, menurut ketentuan Pasal 1 "Di tempat-tempat yang ada Pe ngadilan Negeri ada sebuah Pengadilan Agama/ Mahkamah Syariah yang daerah hukumnya sama dengan daerah hukum Pengadilan Negeri." Sedangkan menurut ketentuan pasal 11 "apabila tidak ada ketentuan lain di Ibu kota provinsi di adakan Pengadilan Agama / Mahkamah Syariah provinsi yang wilayahnya meliputi satu, atau lebih, daerah provinsi yang di tetapkan oleh menteri Agama (Alaiddin, 2011).

Dengan berlakunya PP. 45 Tahun 1957, maka di Indonesia ada tiga macam peraturan tentang susunan dan kekuasaan Peradilan Agama yaitu :

1. Stbl. 1882 No. 152 jo. Stbl 1937 No 116 dan 610 untuk Jawa dan Madura

2. Stbl. 1937 No. 638 dan 639 untuk daerah kalimantan Selatan

3. PP No, 45 Tahun 1957 (lembaran Negara tahun 1957) No, 99 untuk daerah-daerah selain Jawa dan Madura serta Kalimantan Selatan.

Perkembangan selanjutnya setelah PP. 45 Tahun 1957 ada beberapa kebijakan yang muncul sebagai peraturan yang memberikan yurisdiksi yang lebih besar kepada pengadilan di luar Jawa dan Madura yaitu :

1. Penetapan menteri Agama No. 58 Tahun 1957 tentang pembentukan Pengadilan Agama/ Mahkamah Syari'ah di Sumatera yaitu ;

(1) Di daerah Aceh, dengan pengadilan Agama/ Mahkamah Syar'iyah propinsinya di Kutaraja (Banda Aceh) 
(2) Di daerah Sumatera Utara dengan Pengadilan Agama/ Mahkamah Syar'iyah propinsinya di Medan

(3) Di daerah Sumatera Barat dengan Pengadilan Agama/ Mahkamah Syar'iyah propinsinya di Padang

(4) Di daerah Sumatera Selatan, Bengkulu dan Lampung dengan Pengadilan Agama/ Mahkamah Syar'iyah propinsinya di Palembang

2. Penetapan Menteri Agam No, 4 Tahun 1958 tentang pembentukan Pengadilan Agam / Mahkamah Syar'iyah di daerah Kalimantan dengan Pengadilan Agamanya di Propinsi Banjarmasin

3. Penetapan menteri No. 5 tahun 1958 tentang pembentukan Pengadilan Agama Mahkamah Syar'iyah di Sulawesi Nusa Tenggara, Maluku, Irian jaya. Dengan Pengadilan Agamanya propinsinya Ujungpandang(sekarang Makassar) Pada tahun 1970 pemerintah mempertegas keberadaan Peradilan Agama dengan di keluarkannya UU No. 14 tahun 1970 tentang ketentuanketentuan pokok kekuasaan kehakiman. Tahun 1980 lahir keputusan menteri Agama No. 6 tahun 1980 tanggal 28 Januari 1980 tentang penyeragaman nama lembaga menjadi sebutan Pengadilan Agama. (Adbul, 2000)

$$
\text { Contoh kasus dan cara }
$$
penyelesaiannya sebelum Orde Baru adalah sebagai berikut :

a. Kasus dalam permasalahan fasakh

Dalam permasalah fasakh di Jakarta 15 Desember 1964 terjadi kasus seorang istri menggungat cerai karena fasakh setelah suami istri hidup bersama selama 19 tahun, suaminya menderita penyakit menular dan tidak sembuhsembuh jari-jari tangannya hingga membusuk, lagi pula suaminya sering menganiaya istrinya, pengadilan Agama memfasakh pernikahan mereka disebabkan penyakit yang di derita suaminya.

\section{b. Kasus dalam permasalahan Rujuk}

Berbeda pada permasalahan rujuk yang terlihat pada tabel 3 halaman 222 dalam kitab peradilan Agama dalam kitab peradilan Agama di Indonesia karya $\mathrm{H}$. Zaini Ahmad Noeh sebelum tahun 1965 sedikit sekali perkara ruju' dihadapkan pengadilan Agama hal ini karena sulitnya menerapkan paham imam alSyafii dalam peradilan Agama di Indonesia. Menurut paham Al Syafii bahwa suami dapat merujuk istrinya selama dalam masa iddah, yakni bila talak itu merupakan talak raj'i bukan talak ba'in habis masa iddah talak menjadi tetap dan bila orang itu mau hidup bersama kembali harus akad nikah seperti semula. Pada 1962 pengadilan Agama Palembang menetapkan seorang istri yang telah lepas haid tiga kali tidak dapat di rujuk oleh suaminya begitu pula istri yang telah membayar iwadh bagi talaknya, ia pun tidak dapat di rujuk (Alaiddin, 2011)

\section{Rujukan Para Hakim dalam Berperkara}

Berdasarkan ketetapan Menteri Agama Nomor 56 tahun 1998 maka di bentuk 11 kantor Pengawas Pengadilam Agama yang kedudukannya berdampingan dengan Pengadilan Agama /Mahkamah Syariah provinsi luar Jawa, Madura, Jakarta, Semarang dan Surabaya. Selanjutnya dengan peraturan Menteri Agama Nomor 1 Tahun 1963 jo nomor 47 Tahun 1963 lembaga pengawas pengadilan Agama itu di ubah menjadi inspektorat Pengadilan Agama.

Kemudian dalam perkembangan selanjutnya lembaga inspektorat ini pun di hapus dan tugas-tugasnya di masukkan ke dalam kewenangan peradilan Agama tingkat Banding. Kemudian menunjuk 13 buku rujukan sebagai pedoman hakim 
agama dalam mengadili perkara yaitu: al Bajuri, Fathul Mu'in, Syarkawi Alattahrir, Qulyubi Mahalli, Fatkhul Wahab dengan syarahnya Tuhfah, Tagribul mustag, Qarwanin Syah'ah lil Sayyid bin Yahya, Qawaninus Syariah Us Sayyid Sahdaqah Dahlan, Syamsuh fil Faraid, Bughyatul Murtasyidin, al Figh 'Alaa Mazahibil Arba'ah dan Mughnil Muhtaj. (Manan, 2013) UU No. 1 tahun 1974 dan Kompilasi Hukum Islam.

\section{Teori Keberlakuan Hukum Islam}

1. Teori Recpetio in Complexu

Teori Recpetio in Complexu dipelopori oleh L.W.C. Van Den Berg (1845-1927). Van Den Berg mengemukakan bahwa orang Islam Indonesia telah menerima hukum Islam secara menyeluruh. Statua batavia 1642 menyebutkan bahwa sengketa warisan antara orang pribumi yang beragama Islam harus diselesaikan dengan mempergunakan hukum Islam, yakni hukum yang dipakai oleh rakyat seharihari. Untuk keperluan ini, D. W. Freijer menyusun compendium yaitu buku yang memuat hukum perkawinan dan hukum kewarisan Islam (Zainuddin, 2010) Buku inilah yang diberlakukan di daerah jajahan VOC.

Penggunaan kitab mugharrar dan papakem Cirebon serta peraturan yang di buat oleh B.J.D. Cloowijk untuk diberlakukan di wilayah kerjaan Bone dan Gowa, Sulawesi Selatan. Oleh karena itu selama VOC berkuasa dua abad(6021800), kedudukan hukum Islam tetap seperti semula. Berlaku dan berkembang di kalangan umat Islam di Indonesia. Ini semua adalah jasa-jasa dari penyiar agama Islam seperti Nuruddin al-Raniry menulis kitab sirat al-Mustakim pada tahun $1628 \mathrm{M}$.

Kitab ini di analisis oleh Syaikh Arsyad al-Banjari kemudian diberi komentar dalam satu kitab yang berjudul sabil al-Mukhtadin, (jalan orang yang diberi petunjuk ) buku ini menjadi penyelesaian sengketa di antara umat
Islam wilayah kesultanan Banjar. Palembang dan Banten, pada tanggal 25 Mei 1760 VOC mengeluarkan peraturan yang senada di maksud, kemudian diberi nama Resolutie der Indische Regeerling. Saloman Keyzer (1823-1868), dan Christian van den Berg( 1845-1927) menyatakan hukum mengikuti agama yang di anut seseorang. (Zainuddin, 2010)

2. Teori Receptie

Teori ini dipelopori oleh Chirstian Snouck Hurgranje (1857-1936), beliau adalah penasehat pemerintah Hindia Belanda tentang soal-soal Islam di negeri jajahan Belanda, dan di kembangkan secara sistematis oleh C. Van Hollen Houven dan Betrand ter Haar Bzn serta dilaksanakan dalam praktik oleh muridmurid dan pengiktu-pengikutnya. Menurut mereka hukum Islam bukanlah hukum melainkan hukum Islam baru menjadi hukum kalau diterima oleh hukum adat. (Zainuddin, 2010)

\section{Peradilan Masa Kemerdekaan}

1. Pada masa awal kemerdekaan

Pada awal kemerdekaan Republik Indonesia peradilan Agama masih berpedoman kepada peraturan perundang-undangan pemerintah kolonial Belanda berdasarkan pasal II aturan perlaihan UUD 1945 yang berbunyi : "segala badan selama belum di adakan yang baru menurut UUD ini". Pelaksanaan peradilan Agama sebagai pelaksanan kekuasaan kehakiman yang mandiri dihapuskan. Peradilan agama menjadi bagian dari peradilan umum untuk menangani perkara yang menjadi kewenangan dan kekuasaan peradilan agama ditangani oleh peradilan umum secara istimewa dengan seorang hakim yang beragama Islam sebagai ketua di dampingi dua orang hakim ahli agama Islam (Suherman, $\mathrm{tt}$ ).

Pada masa berikutnya berdarkan ketentuan pasal 98 UUD Sementara dan pasal 1 ayat (4) UU Darurat No. 1 tahun 1951 pemerintah mengeluarkan PP No . 
54 tahun 1957 tentang pembentukan Pengadilan Agama atau Mahkamah Syar'iyah di luar Jawa dan Madura. (Suherman, $\mathrm{tt}$ )

\section{Masa Orde Baru}

Sekitar 25 tahun sejak kemerdekaan terdapat keaneka ragaman dasar penyelenggaraan, kedudukan, susunan, dan kekuasaan pengadilan dalam lingkungan peradilan Agama selanjutnya pada tahun pada tahun 1970 Jo. UU no. 35 tahun 1999, dan UU no. 1 tahun 1974 serta peraturan pelaksanaannya. Dengan berlakunya UU No. 14 tahun 1970 Jo. UU No. 35 athun 1999 memberi tempat kepada Peradilan Agama sebagai salahsatu peradilan dalam tata peradilan di Indonesia yang melaksanakan kekuasaa kehakiman dalam negara kesatuan republik Indonesia.

Dengan berlakunya UU No. 1 tahun 1974, maka kekuasaan pengadilan dalam lingkungan Peradilan Agama bertambah. (Suherman, tt) Dalam perkembangan selanjutnya berlakunya UU No. 7 tahun 1989 posisi peradilan Agama semakin kuat dan dasar penyelenggaraannya mengacu kepada pengaturan perundangundangan yang unikatif.

Selain itu dengan perumusan KHI yang meliputi bidang Perkawinan, kewarisan, dan perwakafan, maka salah satu yang di hapadi dalam lingungan peradilan agama adalah yaitu keanekaragaman rujukan dan ketentuan hukum tentang UU No. 7 tahun 1989 serta instruksi presiden No. 1 tahun 1991 tentang penyebar luasan kompilasi hukum Islam.

Lahirnya Undang-Undang Nomor 1 Tahun 1974 tentang Perkawinan memperkokoh keberadaan pengadilan agama. Di dalam undang-undang ini tidak ada ketentuan yang bertentangan dengan ajaran Islam. Pasa12 ayat (1) undang-undang ini semakin memperteguh pelaksanaan ajaran Islam
(Hukum Islam). Suasana cerah kembali mewarnai perkembangan peradilan agama di Indonesia dengan keluarnya Undang- undang Nomor 7 Tahun 1989 ten tang Peradilan Agama yang telah memberikan landasan untuk mewujudkan peradilan agama yang mandiri, sederajat dan memantapkan serta mensejajarkan kedudukan peradilan agama dengan lingkungan peradilan lainnya. (Suherman, tt)

3. Masa Orde Reformasi sampai sekarang

Kedudukan dan kewenangan peradilan Agama pada masa reformasi sejak lahirnya Undang-Undang No. 3 tahun 2006 atas perubahan UndangUndang No. 7 tahun 1989, telah membawa perubahan besar dalam penyelenggaran pengadilan agama baik aspek organisasi, administrasi, teknis peradilan, dan penambahan kewenangan absolute peradilan Agama. Kewenangan absolute Peradilan Agama, sebagai tertuang pada Pasal 49 adalah : Pengadilan agama bertugas dan berwenang memeriksa, memutus, dan menyelesaikan perkara di tingkat pertama antara orang-orang yang beragama Islam di bidang:

a. perkawinan;

b. waris;

c. wasiat;

d. hibah;

e. wakaf;

f. zakat;

g. infaq;

h. shadaqah; dan

i. ekonomi syari'ah.

Ketentuan Pasal 50 diubah sehingga berbunyi sebagai berikut:

(1) Dalam hal terjadi sengketa hak milik atau sengketa lain dalam perkara sebagaimana dimaksud dalam Pasal 49, khusus mengenai objek sengketa tersebut harus diputus lebih dahulu oleh pengadilan dalam lingkungan Peradilan Umum. (2) Apabila terjadi sengketa hak milik sebagaimana dimaksud pada ayat 
(1) yang subjek hukumnya antara orangorang yang beragama Islam, objek sengketa tersebut diputus oleh pengadilan agama bersama-sama perkara sebagaimana dimaksud dalam Pasal 49. Pada Pasal tersebut, kewenangan Peradilan Agama ditambah dengan dengan menangani ekonomi syariah. Yang semula pada undang-undang sebelumnya tidak ada. (Suherman, tt)

\section{KESIMPULAN}

Peradilan Agama di Indonesia pada masa awal kemerdekaan mengalami perubahan yang signifikan di mana pada masa Belanda Sebelum merdeka pegawai pengadilan agama dan hakim tidak mendapat gaji tetap dan honorarium dari pemerintah, maka setelah merdeka anggaran belanja pengadilan agama disediakan oleh pemerintah, meskit ketua pengadilan agama mendapat gaji pada masa kolonial Belanda, tetapi ketika itu gaji itu diberikan bukan atas nama sebagai pegawai pengadilan agama, tetapi menerima gaji sebagai Islamitisch Adviseur pada Landraad.

Peradilan Agama pada awal kemerdekaan pengadilan Agama bukan hanya di Jawa dan Madura akan tetapi sudah sampa ke kabupaten dengan sebutan nama Mahkamah Syar'iyah di Aceh propinsinya di Banda Aceh, Pengadilan Agama di Sumatera Utara di Medan Sumatera Barat di Padang. Pengadilan Agama pada masa awal kemerdekaan untuk Jawa dan Madura masih Nikah, talak, dan rujuk ada perkara-perkara yang tidak masuk di dalam kekuasaan Pengadilan Agama seperti Hadhanah, Waris, wakaf, hibah, dan lain sebagainya.

\section{REFERENSI}

Abbas, Siradjudin. (2004). kumpulan soal jawab keagamaan . Jakarta : Pustaka tarbiyah.

Abdurrahman, Wahid. (1994). Hukum Islam di Indonesia pemikiran dan praktek . Bandung : Remaja Rosdakarya.

Adbul, Halim. (2000). Peradilan Agama dalam Poitik Hukum di Indonesia. Jakarta: RajaGrafindo Persada.

Alaiddin, Koto. (2011). sejarah Peradilan Islam. Jakarta: Rajawali Pers.

Angga Priyatna, Aditya fauzan Hakim. (2013). Nama dan kisah Pahlawan Indonesia dari masa VOC Belanda Jepang hingga masa pembangunan. jakarta : Anak Kita.

Arifin, Jaenal. (2013). jejak langkah peradilan Agama di Indonesia. Jakarta : Kencana Prenada Media Group.

Endang, Anshari. Saefuddin. (1986). Piagam Jakarta 22 Juni 1945 dan Sejarah Konsensus Nasional antara Nasionalis Islami dan Nasionalis Sekuler Tentang Dasar Negara Republik Indonesia 1945-1959. Jakarta: Rajawali Pers.

Jalil, Basiq. (2012). Peradilan Islam . Jakarta: Amzah.

Manan, Abdul. (2013). Peradilan Agama di tinjau dari berbagai aspek. Bogor: Diklat Cakim PPC Terpadu II.

MPR, Pimpinan. M. (2012). Empat PIlar Kehidupan Berbangsa dan Bernegara. Jakarta: Sekretariat Jenderal MPR RI.

R, Ahmad. (2015). Peradilan Agama di Indonesia . Yudisia.

Suherman. (tt). Kedudukan dan Kewenangan Peradilan Agama di Indonesia. al Maslahah Jurnal Hukum Islam dan Pranata Sosia, I.

Supriyadi, Dedi. (2008). Sejarah Peradaban Islam. Bandung: Pustaka Setia.

Zainuddin, Ali. (2010). Hukum Islam pengantar Ilmu Hukum Islam di Indonesia. Jakarta : Sinar Grafika. 
Journal of Islamic Law El Madani

Volume. 1 No. 1. Desember 2021

$\overparen{T I L E}$ 